\title{
From Mersmann to Lewin: Toward a Conceptual Shift Within the Phenomenological Analysis of Music ${ }^{1}$
}

\author{
Martina Stratilková
}

Hans Mersmann (1891-1971), an outstanding German musicologist, addressed music from several points of view. While his early career started with works on pre-classical music, in the 1920s he became a prominent spokesman of New Music. In a study from $1919^{2}$ he outlined some concepts forming a part of his later synthetic views of music: his study of the history of musical style foreshadowed his studies, which were both theoretically and historically well informed, and in which he elaborated a structural apprehension of a musical work. He formulated this approach comprehensively in Angewandte Musikästhetik in 1926, where he pronounced the tenets of the general methodological stance which should be exploited in musicology (phenomenology), and where he defined structural elements of music and the way they were integrated into the musical structure of the historical style periods of classical music. ${ }^{3}$

He found the point of departure for understanding the organization of music in force and its dynamic transformations occurring within a certain context. Music encompasses two dimensions which form a background for something happening. The first dimension can also be treated as horizontal and as temporality, the other as vertical and leading to spatiality. The horizontal dimension is expressed by the force which drives the musical flow towards its continuation in the direction of the future and towards greater power (centrifugal force). The vertical dimension bestows restrictions upon the pushing flow (centripetal force). If a place appears in the musical structure which divides the musical flow, reduces its intensity, and makes it regular (for example, cadence, metre, repeated

1 This article was published under the 2013-2016 project of the Research Support Foundation of the Faculty of Arts, Palacký University Olomouc, entitled Phenomenological Analysis of Music (registration number FPVC2013/14).

2 Hans Mersmann, "Die Sonate für Violine allein von Artur Schnabel," Melos 1 (1920): 406-418.

3 For a more detailed view of Mersmann's analytical approach see my previous study, "Hans Mersmann and the Analysis of the New Music," Musicologica Olomucensia 22 (2015): 109-119. 
tones, or tones from one harmonic function), the significance of the spatial dimension grows. Mersmann offered separate explications of the individual elements of musical structure, among which he distinguished the primary (melody, harmony, rhythm) and secondary (dynamic, agogics, timbre) ones. Within each of these elements he identified patterns of greater or lesser force (tension). ${ }^{4}$ For example, a melodic line bears a high level of tension when it is ascending and an interval conveys a strong force when it is large and the two pitches that form it do not fuse very much.

Mersmann's analytical approach thus begins with a "preparatory enquiry", ${ }_{5}$ which should "loosen the forces operating together in the artwork from their penetration and to understand with the highest possible clarity the structure of each of these forces individually." In Angewandte Musikästhetik or Musik der Gegenwart (Berlin: Julius Bard, 1924), he delivered many examples of the way such analysis might be employed. The second step, in fact "the goal of analysis is synthesis." The tension between temporal force and spatial shaping results in a form-building process: partial force moments (tectonic elements) grow to higher levels of division of the course of the musical work ${ }^{8}$ and as a result phenomenological aesthetics "[...] views the content of music in the sum of its tectonic elements." ${ }^{9}$ Mersmann thus took into account the aspect of unity and integrity because we understand music when it is given to us in meaningful wholes (intentional unities). Identifying unities with the moment of translating various musical qualities to their (more or less) progressive temporality is important for both Mersmann's and Schenker's analysis. For the formulation of the analytical results Mersmann introduced a special graphic depiction, which retained a synthetic character. His analyses of Haydn's Sonata in Eb Major (Hob. XVI: 49) ${ }^{10}$ and Artur Schnabel's sonata are good examples of analysis revealing the "total sum of tensions" ("Gesamtspannung"), ${ }^{11}$ showing Mersmann's strong focus on thematic material, its force characteristics, and the further course arising from it in its force profile.

4 The concept of primary and secondary musical parameters could imply an ideologically imbued stance, but supposedly only if it were understood as disregarding historicity. That is not the case of Leonard B. Meyer and his categorization of primary and secondary musical parameters, which is basic to his book Style and Music: Theory, History, and Ideology (University of Chicago Press, 1989), which seeks a theory of style as a complex of various conditions playing an important role in music making. Unfortunately, Mersmann is not discussed by Meyer.

5 Ibid., 713.

6 Ibid., 713.

7 Hans Mersmann, Angewandte Musikästhetik (Berlin: Hesse, 1926), 713.

8 Mersmann admitted that to define the vertical dimension is rather harder because of its essentially negative nature - it binds the forces together while turning them backwards.

9 Hans Mersmann, “Zur Phänomenologie der Musik," Zeitschrift für Ästhetik und allgemeine Kunstwissenschaft 19 (1925): 376.

10 Cf. Hans Mersmann, "Versuch einer Phänomenologie der Musik," Zeitschrift für Musikwissenschaft 5 (1922-1923): 226-269.

11 Mersmann, Angewandte Musikästhetik, 714. 
Mersmann's approach had much in common with other energeticists, especially with Ernst Kurth, whose books probably acted as an inspiration for him. Their landmark was expressed in a rather philosophical way by Helmuth Plessner, according to whom the musical "course is motivated through the tones themselves", and tones are characterized by a "compulsion to continue". ${ }^{12}$ This forward drive of music was also reflected by the Schenkerian analysis, based on understanding structural tones as the goal tones of the previous musical motion. ${ }^{13}$ We will not devote much place to these theories, which were comprehensively discussed by Lee Rothfarb.

Besides saying that Mersmann's concepts were in many points related to the ideas of these authors, it is mainly noteworthy that the energeticist approach is clearly recognizable in Wallace Berry's Structural Functions in Music $\left(1976,{ }^{2} 1987\right)$. Here Berry introduced a conception of musical structure in which motion and the growth (or recession) of intensity constitute the basis of musical formations of various levels of hierarchy, together with their functions and musical meaning. Similarly to Mersmann, he characterized the individual parameters of musical structure with regard to their tension (or release) potential. In a separate table he specified the "intensity values" of "certain fundamental elements of musical structure". ${ }^{14}$ The idea of progression is then apparently tied up with tension: "The concept of progressive and recessive actions within confluent element-structures suggests the useful basic principle that, in an important sense, there are 'dissonances' and 'resolutions' within all of music's parameters." 15

Though the connection with Mersmann seems to be evident, Berry did not mention any energeticist authors except for Schenker. Besides this structural temporality Berry also employed the notion of levels of musical structure, thus incorporating Schenkerian motifs. ${ }^{16}$ Within this "concept of leveled structure of music" he was referring, for example, to the foreground, background, or middlegrounds. And he also used examples of the grouping of harmonic functions into higher harmonic units. As a whole his system thus incorporates the inheritance of the energeticist stance close to Mersmann, as well as the Schenkerian notion of layers ("levels"): "Musical structure may be said to be the punctuated shaping of time and space into lines of growth, decline, and stasis hierarchically ordered." ${ }^{17}$ Berry's

Helmuth Plessner, "Zur Anthropologie der Musik,” Jahrbuch für Ästhetik und allgemeine Kunstwissenschaft 1 (1951): 110-121, here p. 115.

13 About the concept of Urlinie Schenker stated that "it signifies motion, striving toward a goal, and ultimately the completion of this course." Schenker, cited in Lee Rothfarb, "Energetics," in The Cambridge History of Western Music Theory, ed. Thomas Christensen (Cambridge: Cambridge University Press, 2002), 927-955, here p. 939

14 Wallace Berry, Structural Functions in Music (New York: Dover Publications, 1987), 11.

15 Ibid., 13.

16 Berry acknowledged the inspiration in Schenkerian theory, especially in its definition by Felix Salzer, but he accentuated only a free treatment with Schenkerianism. Cf. ibid., 14.

17 Ibid., 5 . 
theory was likened to Kurth by Benjamin, ${ }^{18}$ and to Mersmann by Rothfarb. ${ }^{19}$ One particular coincidence between Mersmann and Berry can further be mentioned, i. e. the utilization of the concept of an "intensity curve", ${ }^{20}$ which is well suited to graphic depiction. He distinguished three forms of musical motion - progression, recession, stasis - and did not maintain the two-dimensionality of music with regard to the tectonic process - progressing force vs. the form-building significance of spatial elements. Berry dealt with the notion of space, but in an altered meaning of extension in the realm of musical pitch. Among possible ways of applying the notion of waving intensity is Berry's notion of generalized concept of rhythm. Just as tonal, melodic, and harmonic events (changes) express in qualities (of extent of change) and pacing what we can describe as "tonal rhythm", "melodic rhythm," and "harmonic rhythm," so the changes in texture are expressive, in timing and in the nature of change, of what is properly termed "textural rhythm." ${ }^{21}$ It does not come as a surprise that we find similar treatment in Mersmann, in this case with regard to form, where we can observe the "developmental rhythm of the whole movement." 22

Perhaps Berry's suggestion could still be promising, as he did not neglect music with free tonality or atonality in his theoretical and analytical treatment. On the one hand it can be supposed that even in atonal music some traits of temporal propulsion can be distinguished (and Berry regarded them within various parameters of musical structure), only they are not unified by tonality. ${ }^{23}$ But as music develops in time, the temporal order, if not for something else than for proximity, still seems to be the source for the grouping of musical events. ${ }^{24}$

Though it was important for Berry to believe that his approach has a reliable experiential basis, it must be noted that his reasoning gets rather closer to the objectivism of the structuralist stance (see the "structural" in the titles of Berry's publications) than to phenomenology. ${ }^{25}$ The use of graphic treatment similar to that of Schenker, supplement-

18 William Benjamin, "Berry, Wallace.” Grove Music Online. Oxford Music Online. Oxford University Press, accessed December 1, 2016, http://www.oxfordmusiconline.com/subscriber/article/grove/ music/02890.

19 Rothfarb, "Energetics," 949-950.

Berry, Structural Functions in Music, 4.

Ibid., 201.

22 Ibid., 412.

23 In the above example of Berry's and Mersmann's notion of generalized rhythm, we can see the same type of difference (multiple rhythms in Berry, one overall rhythm in Mersmann), though Berry can find help in the Schenkerian treatment.

24 The concept of grouping, implicating rather the temporal field of presence, and that of events, referring temporally to extended wholes, was used by Berry systematically throughout the cited book.

25 Ann K. Gebuhr mentioned Berry directly in connection with structuralist approaches and with Janet Schmalfeldt's consideration, including Berry's book Musical Structure and Performance (1989) among "severe cases of the Analyst as Authoritarian", a strong emphasis on musical work as a clearly defined object can be inferred. Cf. Janet Schmalfeldt, "Response to the 2004 SMT Special Session 'Performance and Analysis: Views from Theory, Musicology, and Performance'," Music Theory Online 
ed with some means of formalized rendering, strengthens the viability of his structural analysis.

The temporality of musical structure is confronted in a rich way with a stronger emphasis on the experience of time in Edward Lippman's Progressive Temporality in Music, which stresses the "feeling that music is progressing or moving forwards" ${ }^{26}$ Let us take a more detailed look at his notion of forward progress in music. Lippman distinguished three types of musical motion: sheer continuity, motivated succession in itself, and the logic of consecution. Continuity seems to be founded simply on a change of individual phases that are bound together. Succession adds to it the momentum of driving intensity, experienced as having its source in the inside. Though only with slight support in Lippman's essay, it can be claimed that in contrast to inwardness, which is proper to succession, continuity stands as something experienced as having its source beyond music. And finally, the logic of consecution arises from the articulations of structural interrelationships between individual phrases and also within each of them. Lippman supplemented his argumentation with musical examples and some generalizing statements on the temporal properties of various structural features of music. He mentioned, for example, short and rapid repeated patterns, forming individual units of perception, which establish the temporal mode of succession. Future-directedness is likewise enhanced by an increase in loudness and speed, (motoric) regularity, rising pitch contour, or cadential resolution. The logic of continuation is represented by a style exhibiting a clear articulation of relationships within the musical structure (e.g. repetition, contrast, or reaction). Referring to the "C preludes" of Bach's Well-Tempered Clavier, he showed how a difference in the arpeggiation figure (the presence of stresses on melodically high points) influences the quality of temporality - how it switches it from a flow of sheer continuation ( $C$ major Prelude) to succession (C minor Prelude).

What next attracts our attention is Lippman's emphasis on the temporality of consciousness and not just its object: "All types of progressive temporality in music must necessarily be grounded in the temporality of consciousness itself [...]." ${ }^{27}$ His discussion can be summarized as being directed to the structure of intentionality grasping auditory objects and their constitution (though Lippman was speaking of production or generation, which would be phenomenologically inappropriate). He expressed basic concepts of the Husserlian phenomenology of inner time-consciousness in his own words: a tonal object occupies the specious present (Husserl: impression) and recedes into the past through the phase of staying in a vivid auditory image (retention) and then to memory (recollection). Lippman only gave slight consideration to the expectation of future continuance. On the other hand,

11, 2005(1), http://www.mtosmt.org/issues/mto.05.11.1/mto.05.11.1.schmalfeldt.html; Ann Karen Gebuhr, Structuralism in Music: a Review of Recent Ideas (Indiana University, 1983).

26 Edward A. Lippman, The Philosophy \& Aesthetics of Music (Lincoln: Nebraska University Press, 1999), 40.

$27 \quad$ Ibid., 61. 
he emphasised the moment of comparing the present with the just-retained: the sense of the actual phase derives itself from its relation to the preceding, now retained phase, and it is experienced as coming from it. This heightened regard for retention mirrors Husserl's own treatise on inner time-consciousness. And so the forward motion is experienced not so much thanks to the connection of the present phase with the expectation of future motion, but first and foremost as the present which "follows from" ${ }^{28}$ what came immediately before. On this basis it could also be better understood why Lippman was not only speaking of a forward motion but also highlighted the backward motion. In his analytical illustration he concentrated mainly on the sources of future-directedness and driving intensity. So it does not come as a surprise that in the case of atonal music every feature of continuity, propulsiveness, and logic as well "is here systematically excluded"; the listener can only enjoy "the successions of single tones, in the relationships of individualized pitches and tone-colors." ${ }^{29}$ Musical pieces that are not organized by tonality exhibit only a limited temporality: in Debussy's music, which preserves tonality loosely, only continuation may be revealed. The notion of loosened continuity in twentieth-century music has been discussed for a long time. We could remind ourselves of Adorno's assertion that new music often takes on the elements of painting and its spatiality increases, in particular in the DebussyStravinsky line. ${ }^{30}$ Later, there appeared yet another conceptualization of such a broken temporality, for example Stockhausen's notion of moment form and the way it was elaborated by Kramer, ${ }^{31}$ who added the concepts of multiple, moment, and vertical temporality. ${ }^{32}$

Musical temporality forms the basis of David Lewin's article Music Theory, Phenomenology and Modes of Perception. ${ }^{33}$ According to Nicholas Cook, phenomenology only entered the mainstream of music theory with this study. ${ }^{34}$ Lewin took as a basis Husserl's general phenomenological methodology as it appeared in Hubert Dreyfus's introduction to the cognitivist version of phenomenology and the Husserlian phenomenology of internal time-consciousness formulated by Izchak Miller. ${ }^{35}$ These sources, which are near to the

\footnotetext{
Ibid., 63.
}

29 Ibid., 57.

30 Cf. Theodor Wiesengrund Adorno, Philosophy of New Music, trans. Robert Hullot-Kentor (University of Minnesota Press, Minneapolis - London [1949] 2006), 140-141.

31 Jonathan D. Kramer, “Moment Form in Twentieth Century Music,” The Musical Quarterly 64 (1978): 177-194.

32 Jonathan D. Kramer, “New Temporalities in Music," Critical Inquiry 7 (1981): 539-556.

33 David Lewin, "Music Theory, Phenomenology and Modes of Perception," Music Perception 3 (1986): 327-392.

34 Cf. Nicolas Cook, "Epistemologies of Music Theory," in Christensen, The Cambridge History of Western Music Theory, 87-105.

35 Hubert L. Dreyfus and Harrison Hall, Husserl, Intentionality, and Cognitive Science (Cambridge, MA: The MIT Press, 1982); Izchak Miller, Husserl, Perception, and Temporal Awareness (Cambridge, MA: The MIT Press, 1984). 
ideas of artificial intelligence, are of great importance because they elucidate Lewin's formal procedures in his accounts of musical perception. ${ }^{36}$

Lewin concentrated primarily on protentional and retentional awareness, i. e. the immediate past retained in consciousness (retention) and expectation of the subsequent musical process. The structure of musical perception shows itself to be recursive, i.e. exhibiting the interrelatedness of the present moment with the past in the form of mutual references of expectation (implication) and fulfilment (implementation of relation to elapsed music). Such a bipolarity, indicated by the mutual relations of formalized units (in examples these are often individual tones) and their constant shifting, probably does not correspond to experience, as Pierre Beaudreau pointed out. ${ }^{37}$ It is questioned whether, when listening to music, we have the feeling that we are moving backwards and forwards in a loop of references, or rather we experience the present as it shifts. As we hear some musically meaningful wholes, these seem to arise "before our eyes" ${ }^{\prime 8}$ as meaningful wholes and when they "are over", they sink into the past like something which has finished. At the same time such a process is repeated with a newly perceived musical flow - another meaningful whole is constituted. And this time it is connected to the previous one, while being constituted from some type of relation to it (see below the "perceptions" and "relations" as parts of the model). It must be noted, again, that this is the situation in tonal music, where it is tonality which grants musical unities. And it is exactly the impossibility of immediate perceptual definition of wholes, resulting to a large degree from their insufficient contrast to one another, that causes difficulties with the comprehensibility of atonal music. Therefore we must conclude that tonal temporality is much more similar to our everyday experience (flow of contrast experiences) than the temporality of atonal music, which loses this chain of changes.

But let us first present the core of Lewin's key to musical perception and consequently the analysis of music:

$\mathrm{p}=($ EV,CXT,P-R-LIST,ST-LIST).

Here the musical perception $\mathrm{p}$ is defined as a formal list containing four arguments. The argument EV specifies a sonic event or family of events being 'perceived.' The argument CXT specifies a musical context in which the perception occurs. The argument P-R-LIST is a list of pairs $\left(p_{i}, r_{i}\right)$; each pair specifies a perception $p_{i}$ and a relation $r_{i}$ which $p$ bears to $p_{i}$. The argument ST-LIST is a list of statements $\mathrm{s}_{1}, \ldots, \mathrm{s}_{\mathrm{K}}$ made in some stipulated language L. ${ }^{39}$

36 Brian Kane especially considered the topic of Lewin's philosophical and conceptual resources to show how they are embedded in the Fregean line of phenomenology pursued at some philosophical schools in the United States. Cf. Brian Kane, "Excavating Lewin's 'Phenomenology'," Music Theory Spectrum 33 (2011): 27-36.

37 Pierre Beaudreau, Recent Contributions to the Phenomenology of Musical Time: A Critical Survey (Montreal: McGill University, 1989), 124.

38 This is what Husserl often said with regard to the immediacy of originary experience; in this context it is not very appropriate, but the visual sphere points well to the experience of wholes.

39 Lewin, "Music Theory, Phenomenology and Modes of Perception,” 335. 
Perception is thus seen as the interplay of several perceptual aspects: events ("real event", "the thing EV", "this" ${ }^{40}$ ), context (it gives the event meaning: it is a frame for the constitution of sense of the event), perceptual relations (such as reinforcement, confirmation, elaboration, realization, modification, sequential expansion, implication, denial, support, and terminal and medial conclusion), and a list of statements (description of perceived music using the language of music theory). Here Lewin used schematic notational examples which can be translated into language as follows: " $p_{3 b}$ denies $p_{2}$ by annotation 'not $\mathrm{V}_{\mathrm{b}}^{6}$ !'”" 11

The model should serve the analysis of the musical work, and the analytical procedure consists of the identification of individual perceptions with the help of the score. The matter of context is crucial here, being a source of various constellations and manifold possibilities of intentional constitution. Lewin's analytical approach thus attempts to present the ambiguity of structural elements: "we are discussing one phenomenon at one location in phenomenological space-time, when in fact we are discussing many phenomena at many distinct such locations." 42

Lewin composed his essay with the support of tonal music but his model is clearly applicable to atonal music too. While Mersmann dealt mainly with general methodological tenets of phenomenology (reduction and intentional constitution), Lewin took a phenomenological tool sensitive to temporality, which is something unique in music. And while it is still probably insufficient for achieving a reliable understanding of all music (e.g. atonal as well), ${ }^{43}$ it stands close to musical perception, because it is treated in a temporal span. But as outlined above, the temporality of tonal music seems to reflect our everyday experience of various events around us, whereas atonal music shifts away from this type experience. In fact we have arrived at Kramer's notion of linearity and nonlinearity in life and art: "the conflict between the fundamental linearity of external life and the essential discontinuity of internal life is not peculiar to the twentieth century. Thought was surely as nonlinear in 1800 as it is today, but now art [...] has moved from a logic that reflects the goal-oriented linearity of external life to an irrationality that reflect our shadowy, jumbled, totally personal interior lives." 44

While tectonics loses its pillars in atonal music, inner time-consciousness does not stop working. That is one of the most important points supporting the potential of Lewin's

40 Ibid., 336. This characterization bears traces of the Fregean model of reference. Lewin's doubts as to whether this item should even be included is truly relevant here because phenomenological reasoning knows a real event only as an already intentional (meaningful) event.

$41 \quad$ Ibid., 349.

42 Lewin, "Music Theory, Phenomenology and Modes of Perception," 357.

43 Husserl emphasised that "[...] what gives unity to the particular object with respect to content [...] analysis of time alone cannot tell us, for it abstracts precisely from content." Edmund Husserl, Analyses Concerning Passive and Active Synthesis, Lectures on Transcendental Logic, trans. Anthony J. Steinbock (Dordrecht: Kluwer Academic Publishers, 2001), 174.

Kramer, "New Temporalities in Music," 544. 
model. What also speaks in favour of it is the plurality of interpretations to which it claims to stay open. Apart from such an interpretative stance, this could be postulated as a result of attentional modification: "[...] in one of the compared cases, one moment of the object is 'favored' and, in another case, another; [...] one and the same moment is 'paid attention to primarily' at one time and only secondarily at another time, or 'just barely noticed still,' if not indeed 'completely unnoticed' though still appearing." ${ }^{45}$ Franz Orlik ${ }^{46}$ mentioned attentional modification with regard to the constitution of meaning. But during attentional modification we have a certain object constituted, a certain noematic core. So attentional modifications cause certain noematic characterizations, but, of course, "[...] without touching the identical noematic core". ${ }^{47}$ The attentional changes referred to do not come from the object as Husserl's conception of constitution assumes, but only from subjectivity. This notion could probably prove to be relevant precisely in the case of atonal music, where the "motivation" of tones mentioned by Plessner and Lippman occurs rather exceptionally. Finally, we must draw attention to Lewin's emphasis on the poetic character of the analysis of music, which then ceases to function as an authoritative set of claims, but approaches a dialogue. Lewin devoted some attention to the "productive modes of behavior", by which he wanted to express that the sense of the world is not given prior to our encounter with it. When we enter into an experience of an object, we constitute it in its sense, but what is more important, and here Lewin abandoned a Husserlian stance in favour of a Merleau-Pontyian perspective, perception itself is penetrated with active behaviour and skill experience. Therefore we are in "danger [...] of ignoring the productive modes of perception" 48 and consequently we should understand a listener as a player and composer as well.

Phenomenological analysis, as we were able to observe it in Mersmann and Lewin, but also in Berry and Lippman, finds its essence in musical temporality. Mersmann and Berry concentrated mainly on the temporality of a musical object, its temporal structure. Lippman was also engaged in the experience of time, carried by music, by which he approached the phenomenology of the life-world being attentive to music as an expression of man's relation to the world. And finally Lewin seems to incorporate all these moments. On the one hand, the formalized nature of his model bears some structuralist attributes, while on the other hand it mainly emphasizes the experience of the listener, and, what is more, this experience is granted performativity. Such a richness and plurality

45 Edmund Husserl, Ideas Pertaining to a Pure Phenomenology and to a Phenomenological Philosophy; First Book: General Introduction to a Pure Phenomenology, trans. Fred Kersten (The Hague: Martinus Nijhoff Publishers, [1913] 1982): 224.

46 Franz Orlik, “'Innere Zeitbewußtsein' und 'attentionale Modifikation'," Archiv für Musikwissenschaft 51 (1994): 253-273.

47 Husserl, Ideas Pertaining to a Pure Phenomenology and to a Phenomenological Philosophy, 224.

48 Lewin, "Music Theory, Phenomenology and Modes of Perception," 386. 
of momentums which could be addressed to tonal and atonal music as well make Lewin's approach plausible.

\title{
From Mersmann to Lewin: Toward a Conceptual Shift Within the Phenomenological Analysis of Music
}

\begin{abstract}
Hans Mersmann presented his concept of musical structure in the 1920s and developed it mainly as a system of form types describing the classical music repertoire. In addition to this, he formulated a set of procedures to be used in the analysis of music. However, with the withdrawal of tonality in twentieth-century music, the significance of his framework for music analysis lessened. Moreover, even within the context of tonal music his approach has not become widely applied. On the contrary, David Lewin's model, developed within phenomenological reasoning sixty years later, despite being a model of musical perception, has turned into an influential theoretical stance with appealing analytical potential. The present paper discusses both approaches against the background of musical temporality and compares their explicative power while considering the advantages of Lewin's model.
\end{abstract}

\section{Od Mersmanna k Lewinovi: ke konceptuální proměně fenomenologické analýzy hudby}

\begin{abstract}
Abstrakt
Hans Mersmann představil svou koncepci hudební struktury ve dvacátých letech dvacátého století a rozvinul ji zejména jako systém formových typů popisujících klasický hudební repertoár. Nadto formuloval řadu postupů, o něž by se měla opírat hudební analýza. Ovšem $\mathrm{s}$ ústupem tonality $\mathrm{v}$ hudbě dvacátého století se význam tohoto rámce snížil. Mersmannův př́stup ostatně nezačal být široce uplatňovaný ani v kontextu tonální hudby. Naopak model Davida Lewina, formulovaný jako model hudebního vnímání a rozvinutý v rámci fenomenologických aplikací o šedesát let později, se stal vlivným teoretickým postojem se zjevným analytickým potenciálem. Předkládaná studie diskutuje oba př́stupy na pozadí hudební časovosti a srovnává jejich explikativní sílu, přičemž zvažuje především výhody Lewinova přístupu.
\end{abstract}




\section{Keywords}

Hans Mersmann; David Lewin; Wallace Berry; Edward Lippman; musical temporality; phenomenological analysis of music.

\section{Klíčová slova}

Hans Mersmann; David Lewin; Wallace Berry; Edward Lippman; hudební časovost; fenomenologická analýza hudby. 